\title{
Water quality assessment of an industrial zone polluted aquatic body in Dhaka, Bangladesh
}

\author{
Mahmuda Akter ${ }^{1, *}$, Tajuddin Sikder ${ }^{1,2}$, A. K. M. Atique Ullah ${ }^{3}$ \\ ${ }^{1}$ Department of Environmental Science, Stamford University Bangladesh, Dhaka-1209, Bangladesh \\ ${ }^{2}$ Department of Public Health, Jahangirnagar University, Dhaka-1342, Bangladesh \\ ${ }^{3}$ Chemistry Division, Atomic Energy Centre Dhaka, Bangladesh Atomic Energy Commission, Dhaka-1000, Bangladesh
}

\section{Email address:}

aktermahmuda.bd@gmail.com (M. Akter)

\section{To cite this article:}

Mahmuda Akter, Tajuddin Sikder, A. K. M. Atique Ullah. Water Quality Assessment of an Industrial Zone Polluted Aquatic Body in Dhaka, Bangladesh. American Journal of Environmental Protection. Vol. 3, No. 5, 2014, pp. 232-237. doi: 10.11648/j.ajep.20140305.14

\begin{abstract}
Water quality in the aquatic body of Dhaka Export Processing Zone (DEPZ) area was studied on the basis of some physiochemical parameters and heavy metal concentrations. Physiochemical parameters like pH, Electrical Conductivity (EC), Chemical Oxygen Demand (COD), Total Dissolved Solids (TDS) and concentrations of some heavy metals like As, Cd, Cu, Co, $\mathrm{Cr}, \mathrm{Fe}, \mathrm{Mn}, \mathrm{Ni}, \mathrm{Pb}, \mathrm{Hg}$ and $\mathrm{Zn}$ were measured. Among different physiochemical parameters, $\mathrm{pH}$, TDS and EC were found within the range. The range of $\mathrm{pH}$ for all of the samples was found from 7.1 to 8.17 and 120 to $450 \mathrm{mg} / \mathrm{L}$ for TDS. The Values of EC were found from 90 to $300 \mu \mathrm{sm}^{-1}$. For $\mathrm{pH}$, EC and TDS, though the ranges were within the limits but there was an increasing trend of the values was observed in every case which is highly alarming. The range of COD values was estimated from 90 to $300 \mathrm{mg} / \mathrm{L}$ and in most of the samples the values exceeded the standard range. The heavy metal containments of the surface water indicated that the concentrations of $\mathrm{Cr}, \mathrm{Cu}, \mathrm{Ni}, \mathrm{Zn}, \mathrm{Hg}$ and $\mathrm{As}$ were obtained below the permissible limit, detection by WHO, 1996. On the other hand, concentrations of $\mathrm{Cd}, \mathrm{Co}, \mathrm{Fe}, \mathrm{Pb}, \mathrm{Mn}$ and $\mathrm{Hg}$ were exceeded the permissible limits. Correlation matrix shows a significant correlation among $\mathrm{Pb}, \mathrm{Cu}, \mathrm{Co}, \mathrm{Mn}$ and Fe. Enrichment factor shows high concentrations of $\mathrm{Cd}, \mathrm{Cr}$ and $\mathrm{Hg}$. Stated environmental condition is highly vulnerable for human being, that's why this is the time to take proper steps for remediation and preventing the pollution around DEPZ water body which is directly related to the industrial emission of DEPZ.
\end{abstract}

Keywords: Water Quality, Physiochemical Parameter, Heavy Metal, DEPZ

\section{Introduction}

Pollution, nowadays, has become a serious concern for human life due to the industrial burst in the world. And, the rivers are the main choices to hold and bear the responsibility of pollutants, especially in the developing countries. Water pollution caused by chemical substances such as heavy metals affects tropical rain forest and river ecology. Heavy metals can accumulate from water to sediments through settling process and some particles can also find their ways into the biota [1]. Bangladesh is said to be the land of rivers [2]. Increasing industrialization and unplanned urbanization have greatly transformed the natural environment, particularly water sector or natural hydrological system of Bangladesh.

The concerns over surface water quality are gradually emerging due to the disposed location of industrial units and the adverse effects on surrounding land and aquatic environment, as well as subsequent impacts on the livelihood system of the local community [3]. Dhaka Export Processing Zone (DEPZ) being the $2^{\text {nd }}$ EPZ of Bangladesh has started its operation in 1993 and at present houses 92 industrial units which are categorically the leading pollution creators. These industrial units in number are as follows: cap/accessories/garments (42); textile/knitting (22); plastic goods (6); footwear/leather goods (4); metal products (2); electronic goods (2); paper products (1); chemical and fertilizer (1) and miscellaneous (11) [2].

Every industrial unit is supposed to have Effluent Treatment Plant (ETP) to treat the respective wastewater they generate. However, so far only a few industries have installed such plants. Even then most of the installed ETPs operate occasionally only to be qualified to international buyers and to get clearance certificate from Department of Environment 
(DoE) [4.]. Most of the industries discharge their effluents containing heavy metals without any prior treatment through open drain and contaminates water, soil and vegetables of the adjacent areas. Pollution from the DEPZ has already affected the wetland and some of the streams ruining aquatic habitats and natural fisheries. Recently, it has been reported that the surface water body connected to DEPZ effluent disposal sites have been steadily contaminated with a huge number of heavy and toxic metals [5].

Therefore, it is an urgent need to figure out the present status of toxic heavy metals in this water body, redress environmental problems and adopt future mitigation strategy [6]. The aim of this work was to investigate the general water quality of the DEPZ adjacent water body. In this purpose we estimated some physiochemical parameters as well as heavy metals (Fe, As, Mn, Co, Cu, Ni, Pb, $\mathrm{Zn}, \mathrm{Hg}, \mathrm{Cr}$ and $\mathrm{Cd}$ ) concentrations. This research will provide a clear idea about the present water quality of DEPZ adjacent area which will be a basis of future research and monitoring activities for preventing water pollution around the DEPZ area and the data generated in this work may help to work out in effluent management strategy towards control over effective treatment of the DEPZ discharges in terms of toxic and heavy metal contents.

\section{Materials and Methods}

\subsection{Study Area and Sampling}

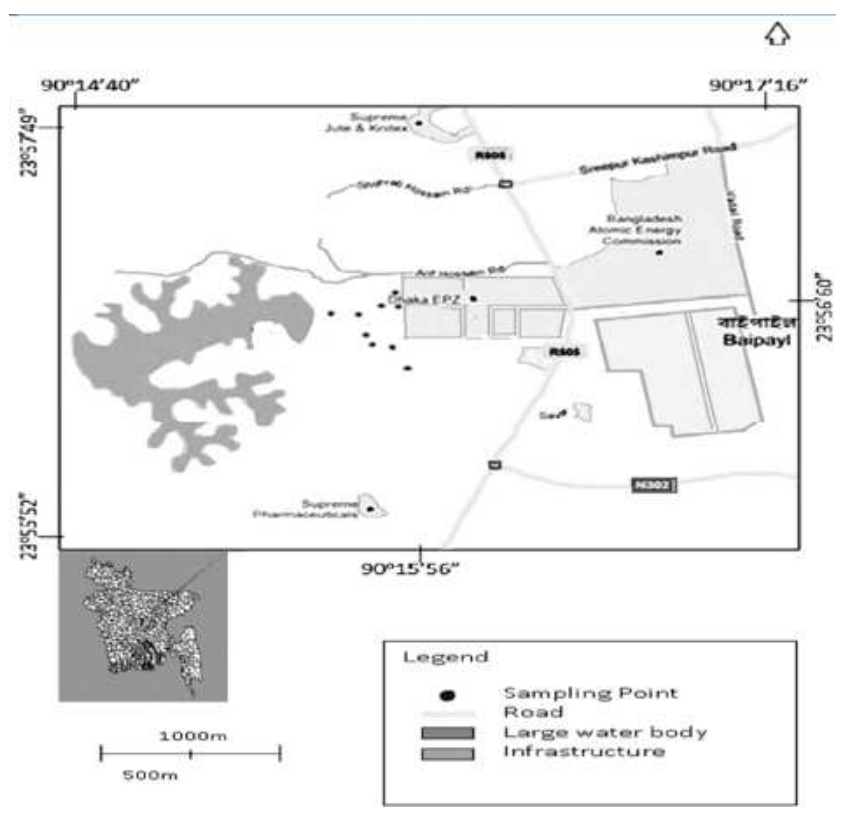

Fig 1. Map of the study area showing the sampling points.

DEPZ adjacent lake water was the study area which is in Dhamsona Union, under Savar Upazila of Dhaka District. It is about $35 \mathrm{Kms}$ from Dhaka city and $25 \mathrm{kms}$ from Hazrat Shahjalal (R.) airport [7]. The area is blazed with numerous industries. There are two export processing zones (old and new) are in service within this girdle. Between these two EPZs the national highway from northern Bangladesh to
Dhaka is running. The present study was carried out in September 2013. All of the samples were collected from the DEPZ adjacent lake water in $23^{0} 57^{\prime} \mathrm{N}$ to $90^{\circ} 15^{\prime} \mathrm{E}$ and are shown in Fig. 1.

For the determination of physiochemical parameters and heavy metal concentrations samples were collected from ten different points in west bill of DEPZ. Samples were collected in $1 \mathrm{~L}$ polyethylene bottles. At first sampling bottles were preconditioned with $5 \%$ nitric acid $\left(\mathrm{HNO}_{3}\right)$ and later rinsed thoroughly with de-ionized water for three times, finally they were dried. At each sampling site, the polyethylene sampling bottles were rinsed with sampling water (water collected for analysis). About 1L of ten surface water samples were collected from ten different places. These places were adjacent areas of DEPZ. The pre-cleaned polyethylene bottles were dipped about $9-10 \mathrm{~cm}$ below the surface of the lake. After collecting the samples the bottles were sealed carefully. The sampling bottles were marked by a permanent marker pen for remarking the sample number and sample location. Then the sampling bottles were transferred to the laboratory for further analysis as early as possible. The water samples were filtered using 41 Whatman filter paper. About $500 \mathrm{~mL}$ of each of the filtered were preserved with ultra pure nitric acid to bring down the $\mathrm{pH}$ to $<2.0$ and also to prevent the absorption of heavy metals onto the bottle for heavy metal analysis. Samples not immediately analysed were kept in the refrigerator at $4^{0} \mathrm{C}$ until further analysis.

\subsection{General Water Quality Parameters}

Some physiochemical parameters were determined immediately in the sampling station. For the determination of $\mathrm{pH}$, a glass electrode $\mathrm{pH}$ meter (Griffin $\mathrm{pH}$ meter, model No.40) was used. The electrode was rinsed thoroughly by using distilled water and wiped by using tissue paper. The electrode was dipped into the sample water and was kept until the stable reading was observed. The EC of water samples were determined by using a digital EC meter (model CON6). An ion selective pack test (Kyoritsu Chemical-check Lab, Corp, Tokyo, Japan) was used according to the instruction manual for the determination of COD. The detection limit of the ion selective pack for COD was $2 \mathrm{mg} / \mathrm{L}$. Internal quality control was used in the measurement of the physiochemical parameters and dissolved metals of the samples in each region. Analytical quality control was assured by replicate analysis of samples. Three replicates of each sample were prepared and their physiochemical parameters were analyzed simultaneously. The TDS of water samples were determined by using a Paul Smith digital TDS Meter. The glass electrode of TDS meter was rinsed thoroughly by using distilled water and wiped by using tissue paper. The electrode was dipped into the sample water and was kept until the stable reading was observed. The final reading was recorded. Another most significant physiochemical parameter $\mathrm{PO}_{4}{ }^{3-}$ of the samples were measured immediately at each sampling point with an ion selective pack test (Kyoritsu Chemical-check Lab, Corp, 
Tokyo, Japan) according to the instruction manual. The detection limit of the ion selective pack for $\mathrm{PO}_{4}{ }^{3-}$ was 0.02 $\mathrm{mg} / \mathrm{L}$.

\subsection{Heavy Metal Analysis}

$250 \mathrm{~mL}$ of samples were taken using $250 \mathrm{~mL}$ volumetric flask and then transferred in a $250 \mathrm{~mL}$ beaker. Duplicates were taken to minimize any error. $3 \mathrm{~mL}$ of $\mathrm{HNO}_{3}$ was taken to each of these beakers and then placed the beaker in a hot plate at approximately $80{ }^{\circ} \mathrm{C}$ covered with watch glass. When the volume of the water was reduced below $25 \mathrm{~mL}$, the beakers were removed from hot plate and cooled at room temperature. The samples were then transferred into $25 \mathrm{~mL}$ volumetric flask through filtration by 40 Whatman filter paper, the watch glass and beaker were rinsed with deionized water and then poured into the flask up to the level. Then the pre-concentrated samples were taken in $25 \mathrm{~mL}$ polyethylene vials. Blank were prepared with $3 \mathrm{~mL} \mathrm{HNO}_{3}$ followed by the similar process. Then the vials were kept to the refrigerator for the next step of the analysis. All chemicals and standard solutions used in the study were obtained from Merck, India/Germany and were of analytical grade. De-ionized water was used throughout the study. All containers and glassware were thoroughly cleaned with detergent powder then soaked in $10 \% \mathrm{HNO}_{3}$ for 24 hours and finally rinsed with de-ionised water for several times.

Flame Atomic Absorption Spectrometer (FAAS) is a very common technique for detecting metals and metaloids in solid and aqueous samples. It is very reliable and simple to use. The technique is based on the fact that ground state metals absorb light at specific wavelengths. Metal ions in a solution are converted to atomic state by means of a flame. Light of appropriate wavelength is supplied and the amount of light absorbd can be measured against standard curve. In this research Varian AA240FS FAAS is used for the determination of concentrations of $\mathrm{Cr}, \mathrm{Mn}, \mathrm{Fe}, \mathrm{Co}, \mathrm{Ni}, \mathrm{Cu}$, $\mathrm{Zn}, \mathrm{Pb}$ and $\mathrm{Cd}$.

Analysis of mercury $(\mathrm{Hg})$ was carried out in Analytical Jena Nov AA350 CVAAS. In this analysis the sample gas was fed into an optical cell by a maintainance-free membrane pump. A beam of UV light passes through the optical cell, a part of it is absorbed by the mercury atoms present in the sample. Therefore, the decrease in intensity of the light source can be used to determine the concentration of the element present in the sample. The graph of the absorbance against the concentration could be plot out with standard solution, thus the reading of the machine can be converted to a result. This method is called "Cold Vapour Atomic Absorption Spectrometer" or shortly CVAAS. It is extremely selective and sensitive. For mercury determination the AAS method has maintained its importance even if other methods have been worked out since the early beginnings. The CVAAS method is low in interferrence and does not require an amalgamation step or carrier gases.

In this study Varian AA280Z HGAAS was used for the determination of Arsenic (As) in the collected samples. Hydride generation sampling systems for atomic absorption bear some resemblances to cold vapour mercury systems. Samples are reacted in an external system with a reducing agent, usually sodium borohydride. Gaseous reaction products are then carried to a sampling cell in the light path of the AA spectrometer. Unlike the mercury technique, the gaseous reaction products are not free analyte atoms but the volatile hydrides. These molecular species are not capable of causing atomic absorption. To dissociate the hydride gas into free atoms, the sample cell must be heated. In some hydride system, the absorption cell is mounted over the burner head of the AA spectrometer, and the cell is heated by an air acetylene flame. In other systems, the cell is heated electrically. In either case, the hydride gas is dissociated in the heated cell into free atoms, and the atomic absorption rises and falls as the atoms are created and then escape from the absorption cell. The maximum absorption reading, or peak height, or the integrated peak area is taken as analytical signal. The accuracy and detection limits depend on the proper isolation of hydride.

\section{Results and Discussion}

The estimated general water quality parameters is listed in Table 1.

Table 1. General water quality parameter of the lake water of DEPZ.

\begin{tabular}{|c|c|c|c|c|c|}
\hline Sample & pH & $\left.\mathrm{EC}(\mu \mathrm{s} \mathrm{cm})^{-1}\right)$ & TDS (mg/L) & COD $(\mathrm{mg} / \mathrm{L})$ & $\mathrm{PO}_{4}{ }^{3-}(\mathrm{mg} / \mathrm{L})$ \\
\hline S-1 & 8.17 & 950 & 400 & 270 & 0.66 \\
\hline S-2 & 8.02 & 945 & 350 & 200 & 0.50 \\
\hline S-3 & 7.82 & 850 & 360 & 300 & 0.43 \\
\hline S-4 & 7.95 & 500 & 280 & 250 & 0.34 \\
\hline S-5 & 7.77 & 745 & 345 & 190 & 0.32 \\
\hline S-6 & 7.92 & 705 & 326 & 100 & 0.27 \\
\hline S-7 & 7.91 & 655 & 300 & 260 & 0.20 \\
\hline S-9 & 7.10 & 300 & 120 & 90 & 0.50 \\
\hline S-10 & 7.79 & 426 & 250 & 100 & 0.50 \\
\hline
\end{tabular}

The $\mathrm{pH}$ maintained by a well-buffered river can be attributed to the fact that, normally, running water is influenced by the nature of the deposits over which the water flows [8]. The $\mathrm{pH}$ values were ranging from 7.10 to 8.17 for the ten sampling points. It can be seen that the ionic environment in the rivers are identical and lies within the standard range recommended by the WHO [9]. Conductivity is a measurement of the ability of an aqueous solution to 
carry an electrical current [1]. The DoE permissible value for $\mathrm{EC}$ is $1200 \mu \mathrm{s} \mathrm{cm}^{-1}$ and the estimated values were found in the water samples ranging from $300 \mu \mathrm{s} \mathrm{cm}^{-1}$ to $950 \mu \mathrm{s} \mathrm{cm}^{-1}$, still which is within the DoE value, but the values shows an increasing trend. All of the values show the trend to decrease with distance as these water mixed with high volume of industrial effluent of DEPZ.

TDS gives the total concentrations of dissolved solids in a water sample. Among these dissolved solids could be phosphates, nitrates, alkalies, some acids, sulphates, iron, and magnesium etc [10].The values of TDS of water samples were determined and the highest value was recorded at 400 $\mathrm{mg} / \mathrm{L}$ in $\mathrm{S}-1$. The ranges vary from 120 to $400 \mathrm{mg} / \mathrm{L}$ for all of the samples, which are within the range of DoE $(2100 \mathrm{mg} / \mathrm{L})$. The highest value goes on S-1 and the lowest value for S-9 and though the values were within the range but the values followed an increasing trend. The highest value was found in the sample which is very close to the point of discharging wastage from different industries.

Chemical Oxygen Demand (COD) values were recorded from 90 to $300 \mathrm{mg} / \mathrm{L}$ and the values exceeded the standard limit in S-1, S-3 and S-5, though the values for other samples were within the range. DoE standard value of surface water for COD is $265 \mathrm{mg} / \mathrm{L}$.

High levels of phosphate as compared with the WHO guidelines were recorded in every case ranging from 0.2 $0.66 \mathrm{mg} / \mathrm{L}$. Standard value provided from WHO is $0.5 \mathrm{mg} / \mathrm{L}$ for surface water. The value exceeded the range in $\mathrm{S}-1, \mathrm{~S}-2$, S-9 and S-10 and the highest value was found in the S-1 (0.66 mg/L).

Concentrations of some heavy metals in the lake water around DEPZ were measured and are given in Table 2.

Table 2. Concentrations $(\mu g / L)$ of metal ions in water around DEPZ.

\begin{tabular}{|c|c|c|c|c|c|c|c|c|c|c|c|}
\hline Sample & $\mathbf{P b}$ & Cd & $\mathrm{Cr}$ & Co & $\mathrm{Cu}$ & $\mathbf{N i}$ & $\mathbf{F e}$ & Mn & $\mathbf{Z n}$ & $\mathrm{Hg}$ & As \\
\hline S-1 & 19 & 3.5 & 3.5 & 4.4 & 3.8 & 7.3 & 77.4 & 4.9 & 26.81 & 3.6 & 4 \\
\hline S-2 & 21 & 2.8 & 4.7 & 5.8 & 2.8 & 6.2 & 161.6 & 30 & 17.08 & 5.9 & 7 \\
\hline S-3 & 24 & 2.65 & 5.2 & 5.1 & 2.3 & 5.6 & 119.6 & 41 & 33.16 & 4.9 & 6 \\
\hline S-4 & 16 & 3.9 & 6.1 & 4.4 & 2.6 & 6.9 & 108.7 & 15.2 & 15.68 & 2.6 & 4 \\
\hline S-5 & 21 & 4.8 & 3.9 & 5.3 & 3.8 & 6.4 & 134.6 & 20 & 19.64 & 2.85 & 3 \\
\hline S-6 & 18 & 2.2 & 7.4 & 4.6 & 3.8 & 6.6 & 139.9 & 35 & 21.56 & 3.2 & 5 \\
\hline S-7 & 23 & 4.6 & 6.3 & 5.1 & 3.4 & 16.3 & 118 & 22.9 & 81.82 & 2.7 & 6 \\
\hline S-9 & 33 & 3 & 6.5 & 17.5 & 9.2 & 5.1 & 1263 & 43.3 & 14.64 & 3.9 & 2 \\
\hline S-10 & 16 & 2.9 & 7.4 & 3.7 & 1.5 & 6.3 & 50 & 7.8 & 18.97 & 5.6 & 4 \\
\hline Average & 22.3 & 3.30 & 5.85 & 6.89 & 4.23 & 8.85 & 418.71 & 26.8 & 26.40 & 3.78 & 4.4 \\
\hline WHO & 10 & 3 & 50 & - & 2000 & 20 & 50 & 10 & 3000 & - & 10 \\
\hline
\end{tabular}

The concentrations $(\mu \mathrm{g} / \mathrm{L})$ of the metals of the water show a wide variation in different metals and in sampling sites. Among the investigated eleven metals, five metals exceeded the standard levels provided by WHO and these are- $\mathrm{Pb}, \mathrm{Cd}$, $\mathrm{Fe}, \mathrm{Mn}$ and $\mathrm{Hg}$. Among these five metals $\mathrm{Pb}$ and $\mathrm{Fe}$ are in extreme level. In addition though other metals are within the range but their gradual increase is alarming for the aquatic ecosystem. The higher range of heavy metals in this study clearly indicates that the area around DEPZ is polluted with heavy metals.

The enrichment factors ( $\mathrm{EF} \%$ ) is usually used to determine water and sediment chemistry in relation to natural and anthropogenic pollution sources. The inclination of metals to accumulate in river water was assessed by determining the
EF (\%) [11]. EF was calculated using following equation-

$$
\mathrm{EF} \%=\frac{C-C_{\min }}{C_{\max }-C_{\min }} \times 100
$$

Where $C$ is the mean metal concentration in the water $(\mu \mathrm{g} / \mathrm{L}), C_{\max }, C_{\min }$, are the maximum and minimum concentrations in $\mu \mathrm{g} / \mathrm{L}$ determined during the study. The calculated values for different heavy metals are listed in Table 3

Table 3. Enrichment Factors of different heavy metals (\%).

\begin{tabular}{lllllllllll}
\hline $\mathbf{P b}$ & $\mathbf{C d}$ & $\mathbf{C r}$ & $\mathbf{C o}$ & $\mathbf{C u}$ & $\mathbf{N i}$ & $\mathbf{F e}$ & $\mathbf{M n}$ & $\mathbf{Z n}$ & $\mathbf{H g}$ & As \\
\hline 37 & 55 & 59 & 23 & 35 & 22 & 18 & 51 & 18 & 38 & 48 \\
\hline
\end{tabular}

Table 4. Correlation coefficient matrix for the metals in the surface water around DEPZ

\begin{tabular}{|c|c|c|c|c|c|c|c|c|c|c|c|}
\hline & $\mathbf{P b}$ & Cd & $\mathrm{Cr}$ & Co & $\mathrm{Cu}$ & $\mathrm{Ni}$ & $\mathrm{Fe}$ & Mn & $\mathrm{Zn}$ & $\mathrm{Hg}$ & As \\
\hline $\mathrm{Pb}$ & 1 & & & & & & & & & & \\
\hline $\mathrm{Cd}$ & -0.16586 & 1 & & & & & & & & & \\
\hline $\mathrm{Cr}$ & 0.2017 & -0.4517 & 1 & & & & & & & & \\
\hline $\mathrm{Co}$ & 0.9152 & -0.2262 & 0.3061 & 1 & & & & & & & \\
\hline $\mathrm{Cu}$ & 0.8898 & -0.1754 & 0.2907 & 0.9417 & 1 & & & & & & \\
\hline $\mathrm{Ni}$ & 0.4491 & 0.1074 & 0.3811 & 0.2649 & 0.4524 & 1 & & & & & \\
\hline $\mathrm{Fe}$ & 0.8624 & -0.2902 & 0.4333 & 0.8724 & 0.9289 & 0.6074 & 1 & & & & \\
\hline $\mathrm{Zn}$ & -0.0321 & 0.4690 & -0.0199 & -0.2713 & -0.2411 & 0.3669 & -0.2935 & -0.1200 & 1 & & \\
\hline $\mathrm{Hg}$ & -0.1819 & -0.4693 & -0.1090 & -0.1637 & -0.3974 & -0.5160 & -0.3034 & -0.0787 & -0.2161 & 1 & \\
\hline As & -0.3896 & -0.1297 & -0.1588 & -0.5929 & -0.6426 & -0.0608 & -0.5538 & -0.0417 & 0.4630 & 0.4355 & 1 \\
\hline
\end{tabular}

${ }^{*}$ Correlation is significant at the 0.5 level. 
The analysis showed that only cadmium, chromium and mercury have high EF values which indicate high pollution level whereas low EF values indicate less pollution level [1]. The standard EF value for the metal is 50\%. Cadmium, Chromium and Manganese already exceeded the standard values whereas Arsenic, Lead and Mercury are in alarming level. Most of the metals are in a trend of increasing the level.

Pearson correlation analysis [12] was performed between all the variables. The level of significance $(\mathrm{p} \leq 0.05$ and $\mathrm{p} \leq$ 0.01 ) of multi-element correlation for water samples was determined and the results are given in Table 4.

The listed $r$ values indicated the high degree of positive correlations and significant linear relation between various pairs of metals, reflecting their simultaneous release and identical source from the DEPZ zone, transport and accumulation in water. The inter-metallic correlation coefficients in the water samples is with $p<0.5$. The significant correlations indicate that they may have originated from common sources, presumably from other industrial (chemicals, paints) activities. The strong association indicates common sources, and these metals may have been derived from anthropogenic sources, especially the paint industry and municipal sewage system.

To determine the common source of metals in the area around DEPZ, a correlation matrix was also calculated for heavy metals in water samples. Table 4 shows significant correlation among $\mathrm{Pb}, \mathrm{Cu}, \mathrm{Co}, \mathrm{Mn}$ and $\mathrm{Fe}$ for lake water. $\mathrm{Pb}$ shows close relationships with $\mathrm{Cu}, \mathrm{Co}, \mathrm{Fe}$ and $\mathrm{Mn}$, suggesting a common source of these metals. Similarly Mn shows a close relation with $\mathrm{Cu}, \mathrm{Co}$ and $\mathrm{Fe}$. At the same way a close relationship is noted between $\mathrm{Cu}$ and $\mathrm{Co}$. Again $\mathrm{Fe}$ shows a close relation with $\mathrm{Cu}, \mathrm{Co}$ and $\mathrm{Ni}$, suggesting a common source of these metals (possibly industrial discharge from paint industry). Alternatively, no correlations are noted between $\mathrm{Hg}$, As, $\mathrm{Cr}$ and $\mathrm{Zn}$ with other metals, suggesting that these metals contamination might be different origin than other metals [13]. A good correlation between Fe and few other metals (Table 4) suggested the diverse source of metals in DEPZ around lake area $[14,15]$.

\section{Conclusion}

It is very important to note that the samples collected from the lake water are free from house hold waste. Industrial waste materials from several industries of DEPZ directly deposited without or with partial treatment. The research work documented in this dissertation describes the pollution status in the aquatic body of DEPZ, which has been studied extensively in terms of relevant physiochemical parameters and the concentrations of some heavy metals. Physiochemical parameters, like $\mathrm{pH}$, TDS and EC are within the range but they show an up growing trend which is highly alarming. In most of the samples the values of COD exceeded the standard range, which is just out of control. In case of heavy metals, the concentrations of $\mathrm{Cr}, \mathrm{Cu}, \mathrm{Ni}, \mathrm{Zn}$, $\mathrm{Hg}$ and As were below the permissible limits whereas those of $\mathrm{Cd}, \mathrm{Co}, \mathrm{Fe}, \mathrm{Pb}, \mathrm{Mn}$ and $\mathrm{Hg}$ exceeded the permissible limits. Correlation matrix shows a significant correlation among $\mathrm{Pb}, \mathrm{Cu}, \mathrm{Co}, \mathrm{Mn}$, and $\mathrm{Fe}$, which indicates a common source of this metal, may be paint industry. Another significant correlation also determined about the common source of the metal and also the contamination level of the sampling region. Enrichment factor also shows actual scenario of the water body. According to this study it can be concluded that the aquatic body around DEPZ is highly polluted for the various types of industrial disposal directly to the water body.

\section{Acknowledgements}

The authors thank the authority of the Department of Environmental Science, Stamford University Bangladesh for providing all logistic supports during the research period.

\section{References}

[1] Sikder MT, Yasuda M, Syawal SM, Saito T, Tanaka S, Kurasaki M. Comparative assessment of water quality in the major rivers of Dhaka and West Java, International Journal of Environmental Protection, 2012; 2(4): 8-13.

[2] Mahbub A, Tanvir HM, Afrin LT. An evaluation of environmental and social impact due to industrial activities- A case study of Bangshi river around Dhaka Export Processing Zone (DEPZ), Bangladesh, International Research Journal of Environmental Science, 2014; 3(2): 103-111.

[3] Islam SMN, Rahman SH, Rahman MM, Adyel TM, Yesmin RA, Ahmed MS, Kaiser N. Excessive turbidity removal from textile effluents using electrocoagulation technique, Journal of Scientific Research, 2011; 3(3): 557-568.

[4] Mortula MM and Rahman MS. Study on waste disposal at DEPZ, Bangladesh Environment (BAPA), 2002; 2: 807-817.

[5] Mahfuz MA, Ahmad JU, Sultana MS, Rahman MM, Goni MA, Rahman MS. Status of physicochemical properties of waste water in Bangladesh: A case studies in Dhalai Beel of DEPZ, Bangladesh Journal of Environmental Research, 2004; 2: 9-15.

[6] Khanam D, Rahman SH, Shahidul Islam MS, Ahsan MA, Shaha B, Akbor MA, Beg RU, Adyel TM. Seasonal Implication of Heavy Metal Contamination of Surface Water around Dhaka Export Processing Zone (DEPZ), Savar, Bangladesh, Jahangir Nagar University Journal of Science, 2011; 34(2): 21-35.

[7] Khan MKA, Alam M, Islam MS, Hassan MQ, and Mansur MA, Environmental Pollution around Dhaka EPZ and its Impact on Surface and Groundwater, Bangladesh Journal of Scientific and Industrial Research, 2011; 46 (2): 153-162.

[8] Hynes HBN. The Ecology of Running Waters, Liverpool University Press, Liverpool. 1997.

[9] WHO (World Health Organization), Guidelines for drinking water quality-1, recommendations. World Health Organization, Geneva, 4th edition, 2011. 
[10] Baird. Environmental Chemistry, Green Chemistry for Environmental Sustainability, 1999; 76: 1639.

[11] Sutar S, Arvind KN, Chabukdhara M, Gupta SK. Assessment of metals in water and sediments of Hindon river, India, Impact of industrial and urban discharges, Journal of Hazardous Materials, 2009; 171: 1088-1095.

[12] Edwards AL.The Correlation coefficient, An introduction to linear regression and correlation, W. H. Freeman and Company: San Francisco, CA, USA Chapter 4, 33-46, 1976.

[13] Sakai H, Kojima Y, Saito K. Distribution of heavy metals in water and sieved sediments in the Toyohira river, Water Resource, 1986; 20: 559-567.
[14] Olivers S, Rieumont D, Rosa DL,Lima L, Graham DW, Alessandro KD, Borroto J, Martinez JS. Assessment of heavy metal levels in Almendares River sediments Havana City, Cuba, Water resource, 2005; 39: 3945-3953.

[15] Sikder MT, Kihara Y, Yasuda M, Yustiawati, Mihara Y, Tanaka S, Odgerel D, Mijiddorj B, Syawal SM, Hosokawa T, Saito T, Kurasaki M. River Water Pollution in Developed and Developing Countries: Judge and Assessment of Physicochemical Characteristics and Selected Dissolved Metal Concentration, Clean- soil air and water, 2013; 41: 6068. 